\title{
In vitro cytotoxicity of the LDE:daunorubicin complex in acute myelogenous leukemia blast cells
}

P.E. Dorlhiac-Llacer ${ }^{1,2}$, M.V. Marquezini2, O. Toffoletto2, R.C.G. Carneiro², R.C. Maranhão ${ }^{3}$ and D.A.F. Chamone ${ }^{1,2,3}$

\author{
'Departamento de Hematologia e Hemoterapia, Faculdade de Medicina, \\ Universidade de São Paulo, São Paulo, SP, Brasil \\ ${ }^{2}$ Fundação Pró-Sangue, Hemocentro de São Paulo, Universidade de São Paulo, \\ São Paulo, SP, Brasil \\ 3Instituto do Coração, Universidade de São Paulo, São Paulo, SP, Brasil
}

\section{Correspondence \\ P.E. Dorlhiac-Llacer \\ Rua dos Escultores, 571 \\ 05469-010 São Paulo, SP \\ Brasil \\ E-mail: llacer.ops@ zaz.com.br \\ P.E. Dorlhiac-Llacer and \\ M.V. Marquezini were supported by \\ Fundação Pró-Sangue (Hemocentro \\ de São Paulo). O. Toffoletto, \\ R.C.G. Carneiro and R.C. Maranhão \\ were supported by CN Pq. Publication \\ supported by FAPESP.}

The present address of

0 . Toffoletto is Hospital do

Rim e Hipertensão, Fundação

O swaldo Ramos, Rua Borges Lagoa,

960, 04038-002 São Paulo, SP, Brasil.

$\ldots \ldots \ldots \ldots \ldots \ldots \ldots$

Received January 19, 2001

Accepted July 12, 2001

\section{Abstract}

Acute myelogenous leukemia (AML) blast cells show high-affinity degradation of low-density lipoprotein (LDL), suggesting an increased expression of cellular LDL receptors. LDE is a lipid microemulsion easily synthesized in vitro which is known to mimic the metabolic pathway of LDL. We used LDE as a carrier for daunorubicin and assayed the cytotoxicity of the complex using AML blast cells since RT-PCR analysis showed that AML cells express LDL receptor mRNA. The LDE:daunorubicin complex killed $46.7 \%$ of blast cells and $20.2 \%$ of normal bone marrow cells $(\mathrm{P}<0.001$; Student $t$-test). Moreover, this complex destroyed AML blast cells as efficiently as free daunorubicin. Thus, LDE might be a suitable carrier of chemotherapeutic agents targeting these drugs to neoplastic cells and protecting normal tissues.

\section{Introduction}

Low-density lipoprotein (LDL) is the lipoprotein that carries most of the cholesterol contained in the plasma compartment and is removed from the circulation into cells by specific receptors on the cell surface (1). The receptors recognize apolipoprotein (apo) $\mathrm{B} 100$, which is the only protein moiety of LDL particles, and apolipoprotein E (apo E) (2). LDL degradation is up-regulated in several cancer cell lines (3), probably because of the great demand of lipids for synthesis of new membranes required by cell proliferation in neoplasia. As originally described by Ho et al. (4) in 1978, LDL degradation reaches up to one hundred-fold that of normal cells in acute myelogenous leukemia (AML) blast cells. It was then demonstrated that LDL could be used as a drug carrier to target neoplastic cells, while avoiding normal tissues and organs (5). Internalization of LDLcontaining chemotherapeutic agents into neoplastic cells resulting in accumulation of the drug in the cytoplasm was in fact demonstrated in several in vitro studies (6-9). Individuals with ovarian and endometrial cancer receiving weekly doses of vincristine complexed with LDL did not show any of the side effects commonly associated with the drug (10). Although this result demonstrates that a chemotherapeutic agent encapsulated in LDL 
can be safely given to cancer patients, the lipoprotein is still difficult to obtain and handle, so that its introduction in clinical practice is rather problematic. Moreover, the use of a human blood product carries the risk of transmission of infectious diseases.

In 1982, Ginsburg et al. (11) synthesized in vitro a microemulsion resembling the lipid portion of LDL. This emulsion (LDE) is composed of phospholipids and cholesteryl esters. When the microemulsion is incubated with high-density lipoproteins or injected into the bloodstream, several exchangeable apolipoproteins shift from the native lipoproteins to the artificial emulsion (12) including apo E. Apo E may permit LDE binding to the LDL receptor (rLDL) (13) and/or rLDL-related protein (14). Several experimental observations on humans and animals have indicated that LDE may be taken up by rLDL and/or by receptors that may recognize apo $\mathrm{E}(12,15,16)$.

The objective of the present study was to determine whether daunorubicin complexed with LDE can also be taken up by neoplastic cells and kill them. This microemulsion was labeled with ${ }^{125}$ I and incubated with K562 cells (a cell line derived from chronic myelogenous leukemia blast cells) and membrane-bound and internalized particles were monitored. Cytotoxicity experiments were performed using the LDE: daunorubicin complex incubated with AML blast cells and normal bone marrow cells.

\section{Material and Methods}

\section{Subjects}

Seven normal bone marrow donors (4 males and 3 females aged 10-40 years) and seven patients with AML (4 males and 3 females aged 15-50 years) participated in the study. The AML patients showed 50 to $92 \%$ blast cells in peripheral blood as diagnosed by cytological, cytochemical and immunophenotyping analysis.

\section{Cells}

Blast cells were obtained from AML patients after hemolysis of whole peripheral blood with $1 \mathrm{mM} \mathrm{NH}_{4} \mathrm{CO}_{3}$ and $144 \mathrm{mM}$ $\mathrm{NH}_{4} \mathrm{Cl}$ for $10 \mathrm{~min}$ at $8^{\circ} \mathrm{C}$. Control cells were obtained from the bone marrow of normal marrow donors. Cell viability was $>98 \%$ as evaluated by the Trypan blue exclusion method. The K562 cell line (17) obtained from a chronic myelogenous leukemia patient was a gift from Dr. R.R. Brentani, Ludwig Institute of Cancer Research, São Paulo, SP, Brazil. The cells were kept in RPMI 1640 (Gibco-BRL, Gaithersburg, MD, USA) containing $10 \%$ FCS (Gibco-BRL) in a $5 \% \mathrm{CO}_{2}$ atmosphere at $37^{\circ} \mathrm{C}$, and were preserved in liquid nitrogen until the time for use.

\section{Preparation of the emulsion}

The emulsion was prepared as described by Maranhão et al. (15). The apo E necessary for binding to the receptor was obtained from FCS (2). LDE was sterilized by passage through a $0.2-\mu \mathrm{m}$ filter and was used in the experiments described below. The LDE emulsion was stable at $4^{\circ} \mathrm{C}$ for four weeks.

\section{Preparation of the LDE:daunorubicin complex}

Two to five milligrams of daunorubicin (Sigma, St. Louis, MO, USA) was diluted in methanol, dried under a nitrogen stream and resuspended in 6 to $15 \mathrm{mg}$ (total lipids) of LDE solution. The mixture was sonicated for 5-10 min using a Branson Cell Disrupter model 450 equipped with a flat tip, with a 20-watt output in the "continuous" operating mode under an $\mathrm{N}_{2}$ atmosphere, with the temperature kept below $30^{\circ} \mathrm{C}$. After sonication the complex was submitted to gel filtration using a PD-10 (Pharmacia LKB Biotechnology AB, Uppsala, Sweden) column equilibrated and eluted with $0.15 \mathrm{M} \mathrm{NaCl}$. The effluent was monitored by absorbance 
at $480 \mathrm{~nm}$. The complex was recovered in the void volume. The amount of daunorubicin incorporated into LDE was estimated by extracting a sample with methanol:chloroform $(1: 3, v: v)$, drying under a nitrogen stream, resuspending the residue with 0.15 $\mathrm{M} \mathrm{NaCl}$, and absorbance reading at $480 \mathrm{~nm}$. The concentration was calculated using a standard curve. Under the conditions used in this experiment the proportion of daunorubicin to LDE in the complex was $10 \mathrm{nmol} / \mathrm{mg}$ of LDE. In all experiments the LDE: daunorubicin complex used was freshly prepared and purified by gel filtration.

\section{LDE labeling}

The emulsion was labeled with ${ }^{125} \mathrm{I}$ in 1 M PBS, pH 9.0 (18), and purified by gel filtration through a PD-10 column equilibrated and developed with the same buffer. About $90 \%$ of the label was found in the phospholipid fraction after $20 \%$ TCA precipitation and thin-layer chromatography. The mean specific activity was $40,000 \mathrm{cpm} / \mu \mathrm{g}$.

\section{LDE binding and uptake}

To determine ideal conditions for LDE uptake, $10^{6} \mathrm{~K} 562$ cells were incubated with $0.1-10 \mu \mathrm{g} / \mathrm{ml}$ (total lipid concentration) of ${ }^{125} \mathrm{I}$ $\mathrm{LDE}$ for $3 \mathrm{~h}$ at either $37^{\circ} \mathrm{C}$ or $4^{\circ} \mathrm{C}$, in $1 \mathrm{ml}$ of RPMI 1640 containing $10 \%$ FCS. After incubation, the cells were washed three times with PBS. To evaluate the plasma cell-bound ${ }^{125} \mathrm{I}-$ LDE, the cells were treated with $2 \mathrm{mg} / \mathrm{ml}$ trypsin for $15 \mathrm{~min}$ at $37^{\circ} \mathrm{C}$ and centrifuged and the supernatant was counted in a gammacounter (COBRA II, Auto-Gamma, Packard, Canberra, Australia). The cells were then lysed with $0.1 \mathrm{M} \mathrm{NaOH}$ and the incorporated ${ }^{125} \mathrm{I}-\mathrm{LDE}$ was determined as described above.

\section{Cytotoxicity of the LDE:daunorubicin complex}

Blast or normal bone marrow cells $\left(10^{6}\right.$ cells) were incubated with $0.1-2.4 \mathrm{nM}$ of either the LDE:daunorubicin complex or free daunorubicin for $3 \mathrm{~h}$ at $37^{\circ} \mathrm{C}$. After incubation, the cells were washed three times with PBS, resuspended in RPMI 1640 without phenol red, incubated with MTT (3-[4,5dimethylthiazol-2yl]-2,5-diphenyltetrazolium bromide thiazolyl blue) for $4 \mathrm{~h}$ at $37^{\circ} \mathrm{C}$ and washed three times with the same medium to remove free MTT (19). The cells were then lysed with $10 \%$ SDS (Sigma) and 0.01 $\mathrm{N} \mathrm{HCl}$ and the incorporated MTT was determined by absorbance at $540 \mathrm{~nm}$ using an ELISA reader (Microwell System, Organon Teknika, Boxtel, Holland). The apparent sensitivity $\left(\log \mathrm{EC}_{50}\right)$ to the LDE: daunorubicin complex was calculated using the Graph Pad InPlot ${ }^{\mathrm{TM}}$ software (Graph Pad Software, Inc, v.4.00).

\section{RNA extraction and RT-PCR analysis}

Total cellular RNA was extracted from $10^{7}$ AML or normal bone marrow cells using Trizol (Gibco-BRL) according to manufacturer instructions. First-strand cDNA was prepared by incubation of $3 \mu \mathrm{g}$ of total RNA (pool of three samples) with Superscript II reverse transcriptase (Gibco-BRL) and random hexamers at $42^{\circ} \mathrm{C}$ for $50 \mathrm{~min}$. Four micrograms of normal bone marrow cDNA or $1 \mu \mathrm{g}$ of AML blast cell cDNA was amplified by PCR using $0.5 \mathrm{U}$ ampli Taq DNA polymerase(Gibco-BRL) and either B-actin primers (sense: 5'-ATCAT GTTTGAGACCTTCAACAC-3'; antisense: 5'-TCTGCGCAAGTTAGGTTTTGTC-3') or LDL primers (sense: 5'-TTGTTGGCTGAAA ACCTACTGTCCC-3'; antisense: 5'-CAA GGCCGGCGAGGTCTCAGGA-3'). To confirm the identity of the rLDL PCR product, a second round of amplification was performed using nested primers (sense: 5'-CAATGTCTC AACAAGCTCTG-3'; antisense: 5'-TCTGTC TCGAGGGGTAGCTG-3') in order to obtain a 273-bp segment. Cycle conditions were $94^{\circ} \mathrm{C}, 4$ min, 35 step cycles $\left(94^{\circ} \mathrm{C}, 45 \mathrm{~s}\right.$; $55^{\circ} \mathrm{C}, 1 \mathrm{~min} 30 \mathrm{~s}$, and $72^{\circ} \mathrm{C}, 1 \mathrm{~min} 30 \mathrm{~s}$ ) and 
$72^{\circ} \mathrm{C}, 10 \mathrm{~min}$. Fifteen microliters of the PCR products was electrophoresed on $1 \%$ agarose gel containing ethidium bromide, and photographs were taken. Samples obtained by omitting cDNA in the PCR mixture were used as negative controls to detect possible DNA contamination.

\section{Statistical analysis}

Differences in cell viability were assessed using the Student $t$-test (20). Two-tailed P values below 0.05 were considered significant.

Figure 1. A, RT-PCR analysis of low-density lipoprotein (LDL) mRNA in normal bone marrow and acute myelogenous leukemia (AML) blast cells. Lane 1: 100-bp ladder; lanes 2 and 3: 4 $\mu \mathrm{g}$ of normal bone marrow cDNA amplified using ß-actin (lane 2) or LDL receptor (lane 3) primers, respectively; lanes 4 and 5: $1 \mu \mathrm{g}$ of AML blast cell CDNA amplified using B-actin (lane 4) or LDL receptor primers (lane 5), respectively. B, The second round of PCR amplification analysis. Lane 1: 100-bp ladder; lane 2: 273-bp segment obtained using nested primers; lane 3: negative control.

Figure 2. ${ }^{125}$ I-LDE binding and uptake by $\mathrm{K} 562$ cells. Cells $\left(10^{6}\right)$ were incubated with $0.10-10 \mu \mathrm{g} /$ $\mathrm{ml}$ (lipid concentration) 125/-LDE for $4 \mathrm{~h}$ in RPMI 1640 containing $10 \% \mathrm{FCS}$ at $37^{\circ} \mathrm{C}$ or $4^{\circ} \mathrm{C}$ (dotted line). After incubation, the cells were washed and treated with trypsin and centrifuged and the supernatant radioactivity (membrane-bound emulsion; dashed line) was measured with a gammacounter. The cells were then lysed and the incorporated radioactivity (solid line) was determined. Each point represents the mean of 2 experiments.
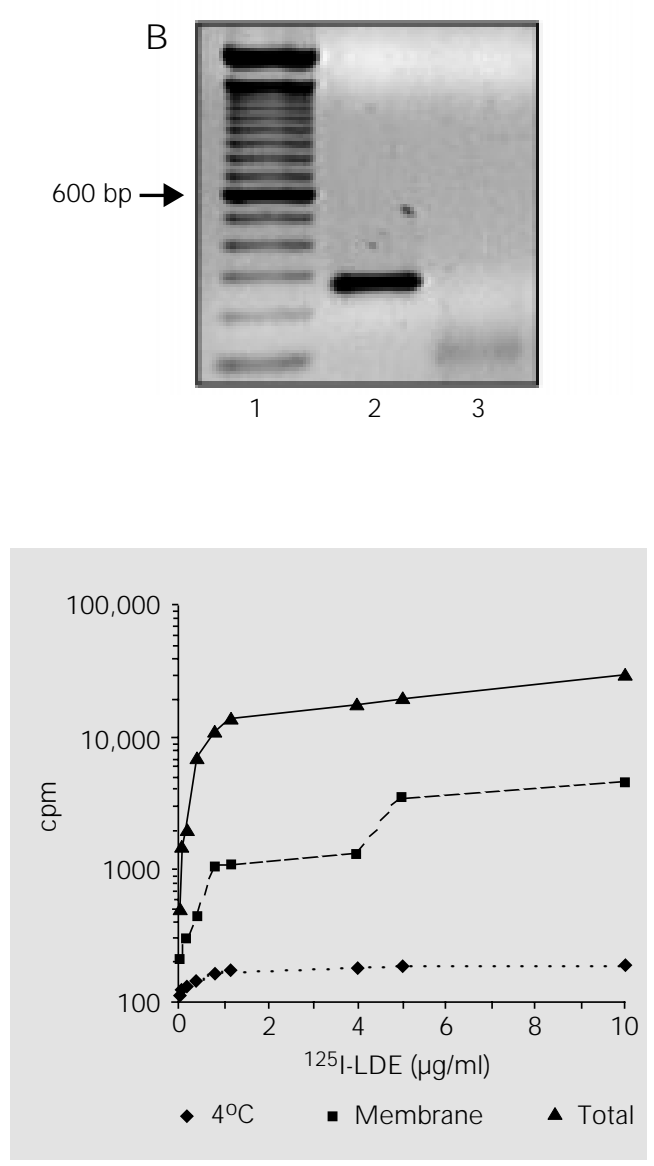

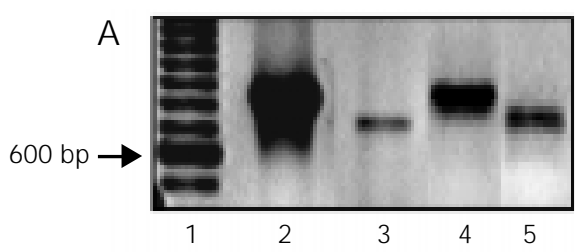

\section{Results}

\section{Transcription of the LDL receptor}

RT-PCR had shown that the expression of rLDL is higher in AML blast cells than in normal bone marrow cells, compared to $B$ actin expression (Figure 1A). The second round of PCR amplification confirmed the identity of the rLDL-amplified product obtained from the first (Figure 1B).

\section{LDE uptake by K562 cells}

Figure 2 illustrates the binding (dashed line) and the uptake (solid line) of ${ }^{125} \mathrm{I}-\mathrm{LDE}$ by $\mathrm{K} 562$ cells. At $4^{\circ} \mathrm{C}$ (dotted line) there was no uptake. Under the conditions used, $90 \%$ of ${ }^{125} \mathrm{I}-\mathrm{LDE}$ was found in the cytoplasm, indicating that the emulsion entered the cell by the endocytic pathway.

\section{Cytotoxicity of the LDE:daunorubicin complex and free daunorubicin}

Figure $3 \mathrm{~A}$ shows the cytotoxicity on normal bone marrow and blast cells of the LDE:daunorubicin complex. A greater cytotoxic effect of the LDE:daunorubicin complex was observed on blast cells than on normal bone marrow cells ( $\mathrm{P}<0.001$; Figure $3 \mathrm{~A})$. This difference was not observed when the cells were incubated with free daunorubicin (Figure 3B). The apparent sensitivity $\left(\log \mathrm{EC}_{50}\right)$ to the LDE:daunorubicin complex did not differ between blast cells $(-9.60 \pm 0.04)$ and normal bone marrow cells $(-9.42 \pm 0.08)$.

\section{Discussion}

One of the major problems associated with the chemotherapy of cancer is the lack of specificity of the drugs, which may give rise to a variety of side effects. A theoretical possibility of reducing the toxicity and improving the therapeutic response is to target 
the cancer cells using a carrier. LDL was proposed as an endogenous carrier in several in vitro studies $(6-10,13,21)$ and proved to prevent side effects in one in vivo study (7). Nevertheless, the routine use of LDL might be difficult due to the problems of its purification.

An alternative to the use of LDL would be an artificial microemulsion (LDE) which resembles its lipid portion (11). Several experimental observations indicate that LDE may be taken up by rLDL and/or by other receptors that may recognize apo $\mathrm{E}$ : a) LDE clearance is accelerated in rats pretreated with $17 \alpha$-ethynylestradiol, which increases rLDL expression (12), b) the LDE biodistribution in humans is very similar to that of LDL (16), c) LDE removal from plasma is increased in patients presenting AML as occurs with native LDL $(3,4,16)$ and after remission of AML, LDE clearance in the patients approaches normal values (16), and d) in vitro experiments with normal leukocytes have shown that LDE competes with LDL for the same receptor (16).

In the present study, we demonstrate that it is possible to incorporate a cytotoxic anthracycline drug into LDE. The LDE:daunorubicin complex obtained by co-sonication of the drug with LDE possibly is due to the interaction of the ring structure present in the daunorubicin molecule that might interact with the interface between the core, composed of cholesterol esters and triglycerides, and the surface, composed of phospholipids and cholesterol. The incorporation procedure is reproducible and a typical preparation contains $10 \mathrm{nmol}$ of drug per $\mathrm{mg}$ of LDE, suggesting a limited number of domains for interaction. Since only a small percentage of the initial drug added $(0.7 \%)$ was found inside highly purified LDE, daunorubicin should be utilized in preparing the complex for therapeutic use in humans or animals. The low incorporation of daunorubicin into LDE observed here was not due to LDE particle characteristics since the same rate of incorporation has been observed using LDL particles (6).

The aim of the present study was to analyze the cytotoxicity of the LDE:daunorubicin complex on myelogenous blast cells and normal bone marrow hematopoietic cells. Comparison of the cytotoxicity of the LDE: daunorubicin complex against normal bone marrow and AML blast cells clearly showed a lower cytotoxic effect on the former. The RT-PCR results indicate that in AML blast cells there is a higher transcription of rLDL than in normal bone marrow cells. Furthermore, the apparent affinity $\left(\mathrm{EC}_{50}\right)$ of both cell types for the LDE:daunorubicin complex did not differ, suggesting that both cells express the same receptor population. In addition, the difference in maximal response between normal and blast cells suggests a higher expression of the receptor respon-
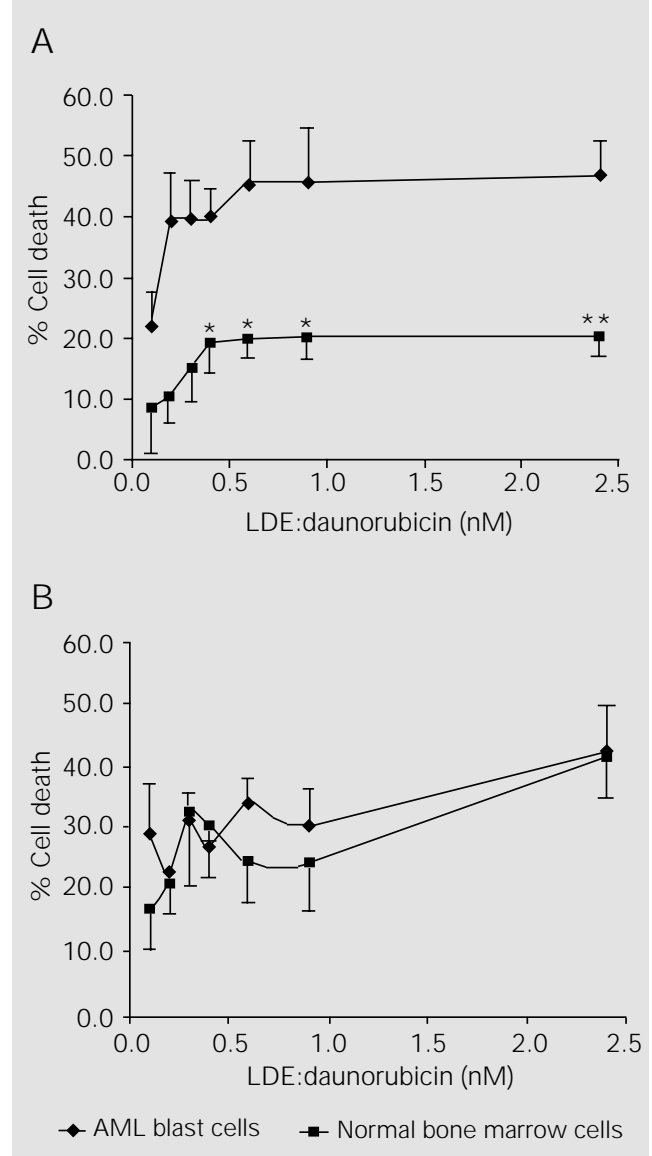

Figure 3. A, Cytotoxicity of the LDE:daunorubicin complex against normal bone marrow cells (squares) and acute myelogenous leukemia (AML) blast cells (lozenges). The points represent the mean \pm SEM of 7-15 experiments. $* \mathrm{P}<0.05$ and $* * \mathrm{P}<0.001$ compared to normal bone marrow cells (Student ttest). B, Cytotoxicity of free daunorubicin against normal bone marrow cells (squares) and AML blast cells (lozenges). The points represent the mean \pm SEM of 7 17 experiments. 
sible for the uptake of LDE in AML. Taken together, these results indicate that the LDE:daunorubicin complex may use the rLDL endocytic pathway to target AML blast cells. However, the involvement of other receptors cannot be ruled out since it has been shown that cell surface receptors such as rLDL-related protein $(14,22)$ can also mediate specific high affinity degradation of ${ }^{125}$ I-labeled LDL.

The complexed drug is as efficient as the free drug in killing blast cells. These results suggest that incorporation does not alter the cytotoxicity of daunorubicin or the receptor binding of LDE. Iwanik et al. (6) showed that the LDL:daunorubicin complex accumulates in P388 leukemia cells, indicating that the incorporation of the drug does not affect LDL binding to the receptor. The in- cubation of free daunorubicin with blast and normal bone marrow cells confirmed the lack of specificity of the free drug.

The LDE:daunorubicin complex has been shown to be effective in protecting normal cells from the toxic effects of the free drug. Highly lipophilic compounds with promising cytotoxic effects in vitro have never reached clinical trials because of difficulties in finding a suitable nontoxic solvent. Our results suggest that LDE might be an interesting and simple delivery system to administer these compounds to tumor cells exhibiting high rLDL expression.

\section{Acknowledgments}

We thank Dr. Regina P. Markus for a critical review of the manuscript.

\section{References}

1. Brown MS \& Goldstein J L (1986). A receptor-mediated pathway for cholesterol homeostasis. Science, 232: 34-47.

2. Zannis VI (1989). Molecular biology of human apolipoproteins $B$ and $E$ and associated diseases of lipoprotein metabolism. Advances in Lipid Research, 32: 1-64.

3. Vitols S, Gahrton G, Öst A \& Peterson C (1984). Elevated low density lipoprotein receptor activity in leukemic cells with monocytic differentiation. Blood, 63: 1186-1193.

4. Ho YK, Smith GS, Brown MS \& Goldstein J L (1978). Low density lipoprotein (LDL) receptor activity in human acute myelogenous leukemia cells. Blood, 52: 10991103.

5. Mosley ST, Goldstein J L, Brown MS, Falck J R \& Anderson RGW (1989). Targeted killing of cultured cells by receptordependent photosensitization. Proceedings of the National Academy of Sciences, USA, 78: 5717-5721.

6. Iwanik MJ , Shaw KV, Ledwith BJ , Yanovich S \& Shaw M (1989). Preparation and interaction of a low-density lipoprotein: daunorubicin complex with P388 leukemic cells. Cancer Research, 44: 12061215.

7. Vitols S, Söderberg-Reid $K$, Masquelier $M$, Sjöström B \& Peterson C (1990). Low density lipoprotein for delivery of a waterinsoluble alkylating agent to malignant cells. In vitro and in vivo study of a druglipoprotein complex. British J ournal of Cancer, 62: 724-729.

8. Firestone RA (1994). Low-density lipoprotein as a vehicle for targeting antitumor compounds to cancer cells. Bioconjugate Chemistry, 5: 105-113.

9. Koller-Lucae SKM, Schott $\mathrm{H}$ \& Schwendener RA (1999). Low density lipoprotein and liposome mediated uptake and cytotoxic effect of $\mathrm{N}^{4}$-octadecyl-1 ßD-arabinofuranosylcytosine in Daudi lymphoma cells. British J ournal of Cancer, 80: 1542-1549.

10. Filipowska D, Filipowski T, Morelowska B, Kazanowska W, Laudanski T, Lapinjoki S, Åkerlund M \& Breeze A (1990). Treatment of cancer patients with a low-density-lipoprotein delivery vehicle containing a cytotoxic drug. Cancer Chemotherapy and Pharmacology, 29: 396-400.

11. Ginsburg GS, Small DM \& Atkinson D (1982). Microemulsion of phospholipids and cholesterol esters. Protein-free models of low density lipoprotein. J ournal of Biological Chemistry, 257: 8216-8227.

12. Maranhão RC, Cesar TB, Pedroso-Mariane SR, Hirata MH \& Mesquita CH (1993). Metabolic behavior in rats of a nonprotein microemulsion resembling low-density lipoprotein. Lipids, 28: 691-696.

13. Vitols S, Gahrton G \& Peterson C (1984). Significance of the low density lipoprotein (LDL) receptor pathway for the in vitro accumulation of AD-32 incorporated into LDL in normal and leukemic white blood cells. Cancer Treatment and Research, 68: 515-520.

14. Rudling M, Gafvels M, Parini P, Gahrton $G$ $\&$ Angelin B (1998). Lipoprotein receptors in acute myelogenous leukemia: failure to detect increased low-density lipoprotein (LDL) receptor numbers in cell membranes despite increased cellular LDL degradation. American J ournal of Pathology, 153: 1923-1935.

15. Maranhão RC, Roland IA, Toffoletto $\mathrm{O}$, Ramires J A, Gonçalves RP, Mesquita CH $\&$ Pileggi F (1984). Plasma kinetic behavior in hyperlipidemic subjects of a lipidic microemulsion that binds to low density lipoprotein receptors. Lipids, 32: 627-633.

16. Maranhão RC, Garicochea B, Silva EL, Dorlhiac-Llacer P, Cadena SMS, Coelho IJ C, Menegheti JC, Pileggi FJC \& Chamone DAF (1993). Plasma kinetics and biodistribution of a lipid emulsion resembling low-density lipoprotein in patients with acute leukemia. Cancer Research, 54: 4660-4666. 
17. Vainchenker W, Testa U, Guichard J, Titeux M \& Breton-Gorius J (1981). Heterogeneity in the cellular commitment of a human leukemic cell line: K562. Blood Cells, 7: 357-375.

18. Langer T, Strober W \& Levy RI (1972). The metabolism of low density lipoprotein in familial type II hyperlipoproteinemia. J ournal of Clinical Investigation, 51: 1528-1536.
19. Dahlin DC, Miwa GT, Lu AY \& Nelson SD (1984). N-Acetyl-p-benzoquinone imine: a cytochrome P-450 mediated oxidation product of acetaminophen. Proceedings of the National Academy of Sciences, USA, 81: 1327-1331.

20. Snedecor GW \& Cochran WG (1980). Statistical Methods. 7th edn. Iowa State University Press, Ames, IA.

21. Rudling MJ, Collins VP \& Peterson CO
(1983). Delivery of aclacinomycin A to human glioma cells in vitro by the low-density lipoprotein pathway. Cancer Research, 43: 4600-4605.

22. Rhainds $D \&$ Brissette $L$ (1999). Low density lipoprotein uptake: holoparticle and cholesteryl ester selective uptake. International J ournal of Biochemistry and Cell Biology, 31: 915-931. 